\title{
Impact of Financial Integration on Ethiopian Economic Growth
}

\author{
Abdulaziz A Hussen \\ Marmara University, Turkey \\ E-mail: zizoahb@yahoo.com; ahussen15@marun.edu.tr
}

Received: November 3, 2019 Accepted: December 1, 2019 Published: December 4, 2019

doi:10.5296/ber.v10i1.15752ＵRL: https://doi.org/10.5296/ber.v10i1.15752

\begin{abstract}
This paper analyzes theoretically the role of financial integration on economic growth and empirically examines the influence of financial integration on Ethiopian economic growth. Many researchers find different investigation results during their data analysis on the impact of financial integration on economic growth. The outcome of most researchers indicate that financial integration has a positive contribution to economic growth, while the result of quite a few numbers of researchers suggested that financial integration has a negative influence on economic growth. Similarly, few of them propose that the relationship between these two variables as bidirectional. Furthermore, literatures categorize the impact of financial sector on economic growth into four basic hypotheses. Which are supply leading, demand following, bidirectional, and independent hypothesis. These hypotheses suggest that financial integration has different role on economic growth and all of them are supported by several research results of various researchers. It is considered that the main reason behind these contrasting research results are the level of financial integration and the composition of financial flows. Moreover, the financial crises that occur in recent decades created a heated debate among researchers on the advantages and disadvantages of financial integration. However, most economists agree that financial integration is beneficial to the economy. The result of this paper analysis also shows, financial integration has a positive impact on the Ethiopian economic performance.
\end{abstract}

Keywords: Financial integration, Economic growth, Financial system, Financial market

\section{Introduction}

This paper makes theoretical analysis on the role of financial integration on economic growth and empirical analysis on Ethiopian economic growth. Though, there is no unanimous agreement on the definition of financial integration, it can be described as a phenomenon of interaction of domestic financial market with international financial market at a regional or 
global level. Financial integration is a process derived from globalization ${ }^{1}$ through financial, economic, technological, political, ecological (environmental), or sociological integration of the world. The benefit of globalization seems to lead financial integration to have a positive role in economic growth. However, the relationship between financial integration and economic growth remains to be one of the most debated issues among international economists and economic researchers after witnessing the worst economic disaster of the global financial crisis. The financial crisis that began in Mexico later in Asia have also brought a light to the growing systemic risks derived from the interdependence characteristics of the financial system, monetary system, and trade system as well as the vulnerability of the developing countries to financial risks due to financial globalization. Financial globalization was a prominent phenomenon of the past few decades. However, there are increasing signs of adverse reaction against it since the above-mentioned financial crisis. As a result, the expansion of financial globalization and the occurrence of international financial crises in last decades have got the attention of economists and policy makers.

Because of this, many researches have been made on this topic to examine the relationship of financial integration and economic growth, to make the cost and benefit analysis of financial integration, to see the extent of its contribution to prosperity and economic growth, and to investigate the role of financial integration in different economic levels or different stages of economic development. Nevertheless, the result of researches on the relationship between financial integration and economic growth is yet inconclusive. Financial integration is one of the main factors that play a big role in the development and modernization of the financial system. The developed and modernized financial system in turn has a greater potential for sustainable economic growth. Financial integration creates economies of scale, increase efficiency and facilitate the availability of funds by making financial markets more liquid. Financial integration process leads to further financial development by promoting competition, expansion of financial markets and financial intermediation. Financial development on the other hand, leads to more efficient allocation of capital resources and lower financial intermediation costs. Allotment of capital resources to the more productive investment, increases the potential for better economic performance. Prasad, Rogoff, Wei and Kose (2003) indicated that financial integration allows households, firms and countries to smooth their consumption or manage changes in revenue by diversifying risks particular to a country. Hence, it could result in bigger increase in social welfare. They say countries borrow from international financial market during economic slowdown to avoid or reduce the negative impact of reduction in aggregate product on consumption and investment. On the contrary, countries provide funds to other countries during economic expansion or service debt they incurred during economic recession.

We do interact with both domestic and international financial system as an individual frequently. Suppose we deposit money into our bank account, we withdraw money for our own consumption, or we take money as a loan; these activities would affect saving and

\footnotetext{
${ }^{1}$ Globalization is the process of developing global influence and creating international interdependence of world society through movement of people, interchange of ideas, flow of investment, exchange of cultures and transfer of technology across international borders that is promoted through international trade.
} 
borrowing of a country's financial system. Or let us say, we are in a market to buy a product made in a foreign country or order online from abroad, these would affect the country's capital flow by contributing to the money flows into or out of the country. Or if we open an individual retirement saving account and invest that saving into an international equity fund, we are participating on the overseas financial flow. Though our involvement in flow of finance overseas in this example does not look as influential as a government economic policy, which can affect international capital flow by large amount by manipulating monetary policy or other economic policies, we do contribute to the capital flow of a country. Therefore, our activity may affect domestic currency circulation, foreign exchange, current account of balance of payment, savings, investment, and overall domestic and international economic activities through financial system.

In addition, international finance mainly deals with issues related to monetary interaction of individuals, companies, or countries. It focuses on topics such as exchange rate, foreign direct investment, monetary system, and issues related to international financial management. International finance is the result of the economic interactions of households, firms or countries at a global level. These activities of global economic agents make them to deal with the issues of compared currencies. Moreover, this international financial interaction makes them also understand the international transaction of goods and services and the determining factors of international prices. This leads them to understand the concept of international trade as an important factor of growth and development of an open economy.

Moreover, international finance plays a major role in international trade of goods and services. It helps to know exchange rates, investments on international debt securities, inflation rates, economic status and foreign markets. International finance helps us calculate exchange rates which is very important to determine the relative values of nations currencies. Various economic factors such as interest rates or cost of borrowing, economic growth or changes in demand, sureness of expectations, technological innovations or productivity of capital, access of funds or availability of finance, and other factors like depreciation, wage costs, inflation, and government policy are factors that help determine whether to invest in foreign debt securities or not to.

In reporting financial statements, countries adopt International Financial Reporting Standards (IFRS) in international finance to have a uniform, coherent, free of deceit and equivalent reporting accounting standard around the world. International finance has expanded due to increasing globalization and makes international economic agents to understand the principles of international financial institutions such as International Monetary Fund (IMF) and the World Bank. An international financial system helps maintain peace among countries. The Global (2018) indicates that the financial system alleviates the efficient allocation of financial capital by giving access to savings and facilitating safe payments. Financial system provides financial security and sharing risks. Extensive and reliable access to financial services is crucial for a sustainable economy.

The possibilities of international financial crises ensued in the existence of international financial system. Hence, the study of international finance is becoming an important subject. 
To be familiar with the issues of the global financial crises, it is required to realize the essential qualities or characteristics of international financial system. Hence, the international financial system needs to be well regulated in order to avoid the chances of disagreements and deceptions among the international financial market players. Therefore, the existence of international financial system makes the international financial matters to be managed systematically in a disciplined manner. Financial system provides different financial services such as allocating and mobilizing capital, supervising investment, facilitate transaction, diversification and management of risk.

Therefore, while discussing about financial integration, it is very important to talk about financial system. Financial system is a closely linked or interconnected networks of financial intermediaries, agents, procedures, transactions, claims, liabilities, financial facilitators, and financial markets that serve to allocate capital, sharing risks and facilitate all types of transactions within an economy. It is a system that enables the transfer of funds between investors and borrowers. Financial system has five major components which needs to be fully interconnected for the financial system to perform efficiently. Theses major components are money, financial institutions, financial instrument, financial market, and central banks. The financial system provides the basic and fundamental services of transferring funds from savers to borrowers. In other words, financial system allows savers to provide money to borrowers. These funds are intermediated by financial institutions such as banks, credit institutions, or directly through financial markets by issuing security.

An efficient allocation of financial resources, in a situation of financial stability, makes a positive contribution to economic growth and development. The most important source of funds are usually households; however, firms, and governments can also be source of funds. On the other hand, the principal users of funds are mainly firms and governments, however, households also may use funds to finance their transaction. Normally, funds flow from lenders to borrowers through two channels which are direct finance such as financial market and indirect finances through financial intermediaries in the financial system. Debtors borrow funds in the financial market to get financed directly from creditors operating in the financial markets by selling them financial instruments such as securities or shares which can be claimed on the borrower's future income or assets. The financing of funds that is obtained through participation of financial intermediaries such as banks or credit unions is referred to as an indirect finance.

One of the features of a well-functioning financial system is to foster an allocation of financial capital resources that is most important to promote economic growth. This type of financial system does not easily be affected by international financial crises and can provide its fundamental services even under difficult financial or economic situations such as international financial crisis or economic recession. A well incorporated financial components of financial system facilitate the develop of financial system infrastructure such as payment and settlement systems, through which financial market activities are accurately carried out. A consistent and reliable operations of financial payment and settlement systems encourages the effective movement of financial capital in the economy and thereby support financial stability. As it is said earlier, a well-functioning financial system and a well-integrated 
component of financial system plays a vital role in efficiently allocating capital resources and fostering economic growth. However, a financial system that is not sufficiently incorporated with its components entails a cost in terms of forgone economic growth. Frey and Volz (2011) and Kose et al. (2009) stated that a certain level of financial development and institutional development is needed before an economy can get optimum benefits and reduce risks of weakening of its capital account.

Financial integration generates a lot of cross-border capital flows between developing and developed countries, and among developed countries. This condition attracts global financial markets to come together and intensify the presence of foreign financial institutions across the world. As a result, developing countries that welcomes a large amount of capital flows are more vulnerable to the financial crisis than developed nations. An unrestricted capital flows to developing countries creates macroeconomic implication. Consequently, there has been a heated argument among researchers, policy makers and academicians regarding the cost and benefit of financial integration to the economy. Many researchers made their analysis on the relationship between the financial integration and economic growth, the role of financial integration on economic growth and the financial sector contribution in fostering the economic growth in general. Their findings indicate that there is no consensus among researchers on the role of financial integration on economic growth. According to some researchers, for a country to benefit from financial integration the country's financial sector development matters. Because, countries with deep financial development benefit more from financial integration than less financially developed countries.

Therefore, this paper tries to examine the contribution of the financial integration on Ethiopian economic growth. And tries to answer the following questions: - does the international financial integration affect Ethiopian economic growth? How does the global financial integration affect Ethiopian economic growth? or to what extent that the world financial integration is playing its role on Ethiopian economic growth. The main objective of this paper is to examine the role of financial sector in Ethiopian economy, to investigate the level at which the financial integration is contributing to Ethiopian economic growth, and to analyze how financial integration is affecting the Ethiopian economy. The paper may contribute to existing literatures on financial integration and economic growth nexus. The role of financial integration on economic growth is still a controversial topic. Some researchers indicated that the benefit from financial integration depends on the stage of a country's financial sector development. This paper contributes in investigating the role of financial sector in economic growth. Considering the level of Ethiopian economic growth and financial sector development of the region and the world at this moment, this paper signifies in examining particularly the role of financial integration on Ethiopian economy. It focuses on the link between the financial integration and Ethiopian economic growth making a country-based analysis to examine the link between these two variables.

This paper is organized into six sections. The first is the introduction part, which gives brief description about the financial integration and its impact on economy, general idea regarding the statement of the research, objective of the paper, the scope and significance of the paper, and organization of the research paper. The second is definition of financial integration, 
which gives brief description about financial integration meanings and concepts. And the third is financial integration theory and literature review. In this part, it tries to review previous related researches on financial integration and its relationship with economic growth in general and particularly tries to review previous researches done on financial sector on Ethiopian economy. The fourth section is methodology part which states how the research paper is collected data, the type of data used, the variables used in regression analysis, and the statistical estimation techniques or the method of regression analysis. The fifth section is data analysis and results, which discusses on the analysis and informs about the result. The six is conclusion and summarizes the idea of the paper and gives recommendation.

\section{Definition of Financial Integration}

Literatures point out that there might be no universally accepted definition of financial integration. However, this paper tries to put certain definitions given by some writers taking them as a sample for the definition given on financial integration. Most literatures give definition of financial integration as the process through which the financial market of a country is connected to a regional or global financial center. The connection of the country's financial market to the world financial center may occur in the forms of cross-border capital flows, unification of market infrastructure, sharing of information, or foreign participation in domestic market. There are several theories that underline the concept of international financial market integration. They discuss about the existence of mutuality between financial markets and the fundamentals for their interactions within or across the border. Several alternative definitions of financial integration were given by different literatures. For example, Baele et al. (2004) indicated that a financial market is considered sufficiently integrated if:

a) If it deals with the same set of rules of financial market

b) If it gives equal opportunity for the same set of financial market

c) If it treated functions of finance equally in the financial market

The explanation of financial market integration is closely related to the law of one price which states that if assets have similar or identical risks and returns, then they should be priced identically regardless of which country they are purchased from. i.e. if a firm issues bonds in two different countries or regions, it should pay the same interest rate to bondholders of both countries or regions (Jappelli and Pagano,2008). If the law of one price does not apply, then there will be a possibility for arbitrage. The presence of arbitrage in an impartial environment allows any investor to freely derive a benefit from any existing arbitrage opportunities which in turn makes the arbitrage to disappear and restore the law of one price. Baltzer et al. (2008) says if all economic agents face the same rules meaning have equal access to the financial market and treated equally in the financial market, any price difference between two identical assets with identical risks and returns, will cease to exist by arbitrage. Brouwer (2005) argues that financial market integration is the process of financial market through which an economy of a certain country becomes more integrated with the rest of economies in the world.

Economic commission for Africa (2008) and Baele et al. (2004) consider three widely 
accepted interrelated advantages of financial integration.

a) It gives better risk sharing and diversification opportunities

b) It creates opportunities for efficient allocation of financial capital which in turn facilitates suitable condition for investment and more economic growth

c) The creation better allocation of capital resources results in financial development

Eyraud, Singh, and Sutton (2017) gave the definition of financial integration as the process of financial markets where two or more countries or regions establishes further relations to one another. They also indicated that financial integration is a multifaceted concept with no universally agreed definition. They highlight two main financial integration indicators which are the level of cross border financial flow and the stages of consolidation and convergence across financial markets.

IMF (2016) defined financial integration as the process where the financial markets of two or more countries or regions become more connected through establishing further relations to one another in financial services and international trade. Financial integration has various forms which are cross-border capital flows, foreign engagement in domestic markets, sharing of information among financial institutions, or merger of financial market infrastructures. Financial integration ca be regarded as a regional or global, depending on a country's financial market association or linkage to neighboring countries or to global financial centers or institutions. Asian Development Bank (2013) defines financial integration as a process of financial market that is motivated by liberalization of domestic financial market and capital account relaxation.

\section{Theory of Financial Integration}

Based on the above definitions, financial integration is the procedure where the financial markets of two or more countries or regions establish further relations in financial services and international trade to create a well-integrated regional or global regulated financial system. The process could be through cross-border flows of capital, foreign involvement in domestic markets, sharing of information among financial institutions, or harmonization of market infrastructures. Based on a country's connection of financial system to region or global financial institutions, the financial integration can be considered as regional or global integration. Theoretically, integration could be seen by the convergence of prices of goods and services with similar risk and returns irrespective of their location. Financial integration can be mainly determined by the cross-border flow of financial capital and the stages of convergence of asset prices. The convergence of financial market structures facilitates and produce inducement for cross-border capital flows, while financial openness offers opportunities to import financial institutions alleviating for greater unification across markets.

In other words, Financial integration is a situation where there is no discrimination of economic participants in their access to capital resources or investment of capital. i.e. financial integration is attained when there is equal access of financial market. Therefore, one would anticipate seeing a substantial cross border portfolio of financial assets and a convergence of asset prices and yields across borders. Financial integration follows the law of 
one price, on condition that the assets have the same cash flows and are affected by identical risk factors. However, when differentiation of yields across borders is detected, the noticed differentiation may not be adequate prove of market fragmentation, it may just mean that markets are pricing different risks differently. Similarly, different interest rates on loans to small and medium enterprises located in different countries may show different productive capacity. On the other hand, the convergence of sovereign yields across countries before the financial crisis may not imply market integration. In other words, convergence of prices may not necessarily mean integration.

The process of financial integration requires opening of a country's financial markets and financial institutions to foreigners and allowing domestic market participants to invest abroad. This is done by removing barriers or obstacles to the cross-border flow of capital and financial services. This results in less favorable treatment of foreign capital and foreign financial institutions. A country can be financially integrated with the world or with the region where it is located. World financial integration leans to take the form of increased financial linkage with major world financial centers as network externalities give them an advantage in the provision of financial services. However, geographical closeness is a significant influencing factor of international trade and cross-border financial flows, and therefore economic growth could be given a higher encouragement by regional financial integration. Literatures show that there are three main driving forces of widening the link of financial integration.

a) The behavior of market players. For example, increased accessibility of information due to the advancement of computing and communication technology.

b) Unilateral action of countries. For example, various emerging economies have eased financial sector regulations and implemented financial market reforms in 1980s.

c) Multilateral action of countries. The international community has formulated standards of financial systems and countries fit in their national financial system with the standards. Moreover, financial integration has been encouraged via formal trade and investment agreements.

How financial integration came into being? Financial globalization played a big role for the birth of financial integration which involves liberalization of capital market. After the World War II, with the establishment of Bretton Wood system, countries started prioritizing financial integration by making reforms in their financial sector. Later, the failure of the Bretton Wood System led to the development of international capital market. Countries started to liberalize their financial system. Literatures show that African countries took liberalization reforms in 1990s. While East Asian countries were a bit earlier to liberalize their capital market and later their interest rates. South Asians also exercised easing regulations in their interest rates and equity markets. Moreover, Latin America as well opened its financial system to foreigners. This condition led to the international financial integration. Does this phenomenon helped countries to perform better in their economic growth? How does this affect the country's economic performance? To answer these questions, it needs to review various literatures before moving to a country specific data analysis. As highlighted on the introduction part, different researches suggested different points based on their research results. Various 
literature review will be presented as follows.

As said earlier, many researchers made their investigation on the relationship between financial integration and economic growth. However, there is no unanimous agreement or consensus in their research results. That could be due to the type of the economies they took into analysis, the data used, or the level of financial infrastructural development variation between the countries. Osada and Saito (2010) indicated in their research results that the effect of financial integration on economic growth differ substantially based on the type of external liabilities in FDI and equity liabilities and debt liabilities. The financial integration levels and the composition of financial flows are the major reasons why countries have undergone a contrasting experience during international financial crisis (Lane,2012) and (Didier et al., 2012). According to literatures, different research results were found. Some say financial integration has a positive impact on economic growth while others say the impact is negative. But still there are quite a few of them showing the relationship is bidirectional or inconclusive.

To give some examples of the literatures, we will begin with those literatures which show the positive impact. Levine (2001) indicated that financial integration has a positive effect on economic growth by amending financial market and financial institutions such as banks. Henry (2000) investigated the effect of stock market liberalization on investment and determined that the stock market liberalization is a determinant factor for investment. Kose et al (2003) reported that the consumption output unpredictability reduces as financial integration enhances. Bekaert and Harvey (2000) pointed out that capital market liberalization contributes to a reduction in the cost of capital. Furthermore, their results indicate that countries with higher degree of foreign ownership go through a much larger reduction in the cost of capital and the decrease continues after liberalization as well. Quinn (1997) and Klein and Olivei (2005) discovered a positive coefficient of correlation between capital liberalization and economic growth. Klein (2005) and Levine (2001) have supplied empirical evidences on impression that states financial liberalization encourages economic growth when financial markets are better developed, and countries have well developed institutions. Kose (2009) provided empirical evidences on the idea that for a country to benefit from capital flows and to mitigate the risks associated with it, it needs to meet some initial set of circumstance in economic policy related features such as financial sector development and development of institutional quality. In neoclassical growth model ${ }^{2}$, financial liberalization facilitates efficient allocation of capital through providing the flow of resources from capital rich or developed countries to capital scarce or developing countries. The flow of resources into capital scarce countries shrinks the cost of capital, thereby,

\footnotetext{
2 In neoclassical growth model, the cobb-Douglas production function: Y1 $=$ AKi $\alpha$ Li $1-\alpha$, States that the economy show a tendency to grow quicker at a lower stage of initial capital-labor ratio than at a higher level of capital-labor ratio. i.e. If capital shows decreasing returns $(\alpha<1)$, an economy with lower capital-labor ratio demonstrates a higher marginal product of capital, thereby, grows faster compared to an identical economy with a higher capital-labor ratio. The differences across countries will incline to disappear gradually, with per capita income and its growth rate converging over time until reaching a similar long-run equilibrium stage for both countries, respectively.
} 
increases investment and economic growth.

The literatures that show the negative impact of financial integration on economic growth are as follows: these researchers believe that the free flow of capital broadens the wealth gap between developed and developing countries and discloses domestic financial systems to risk of instability. They accuse financial integration for raising a country's exposure to international financial crises, which inclines to happen during periods of sudden reversal in international capital flows. The sudden reversal could be due to the increase of interest rate in more stable country and due to domestic condition of the country like political instability or economic slowdown that discourages foreign direct investment. If this happens, the country usually suffers from liquidity crisis ${ }^{3}$. Concerns related to such reversals were increased due to experiences of a series of financial crises such as the 2001-2002 Argentine peso crisis, the 2001 Turkish lira crisis, the 1999 Brazilian real collapse, the 1998 Russian crisis, the 1997 Asian crisis, and the 1994 Mexican peso crisis.

A country may attract a large volume of international capital. However, at some point, the inflow of international investment may reverse due to several factors as said earlier such as change in interest rate, domestic political conditions, or panic related to investment in emerging economies. Foreign investment may stop everywhere regardless of whether the country has any specific problems or not. When foreign investment stops suddenly, the country may suffer from liquidity crisis. At normal times, new investment is used to pay the interest on existing international debts. Now, suddenly, there is no new international investment. As a result, the country is forced to use its foreign exchange reserves to service its debts. However, the foreign exchange reserve of a country is limited and when a country decides to do so, the investor panic intensifies. As a result, the domestic currency may depreciate sharply creating inflation and recession. To avoid this, countries should not depend on high foreign capital and high foreign debt. Rather, they should try to attract more foreign direct investment instead of portfolio investment which is debt and equities. Because, foreign direct investment is more stable and less vulnerable to sudden stops and reversals. This helps them to keep large foreign reserves that can be used as a buffer if a sudden stop occurs.

Financial globalization is considered as one of the phenomenon that contribute to the occurrence of the financial crisis and its dispersion all over the countries through its effect on speedy domestic credit growth and current account disequilibrium (Claessens et al, 2010), (Giannone et al., 2011) and (Lane, 2012). Using cross country data several empirical studies like Claessens et.al. (2010), Rose and Spiegel (2010), Lane and Milesi-Ferretti (2011), Frankel and Saravelos (2012), Eichengreen (2010) have shown that developed countries have endured more than emerging economies and developing economies during the financial crisis. Lane (2012) and Didier et al. (2012) have shown that different financial integration stages

\footnotetext{
3 When international investments are utilized as a source of payment for an interest rate of an existing international debts, an expected absence of new international investments may force the country to use its foreign exchange reserves to service its debt. This results in the reduction of the country's foreign reserves and intensifies panic to investor. This makes the currency to depreciate sharply thereby creates inflation and recession in the economy.
} 
and structure of financial flows in developed and emerging economies are indicated as the major cause behind the contrasting experience of those countries during international financial crisis. Even though both developed and emerging countries have achieved high levels of financial integration, emerging economies appear to have a lower susceptibility to international financial flows compared to the developed economies. As pointed out by Lane and Milesi-Ferretti (2007), Lane and Shambaugh (2010), and Prasad (2011) emerging economies have substantially decreased their net external liabilities by creating current account surpluses and improving financial liquidity through accumulation of foreign exchange reserves.

Therefore, contrasting with their experiences in the post financial crisis, a decrease in value of exchange rate during 2008 and 2009 financial crisis, contributed to an improvement in their external financial assets and liabilities. These changes in their debt profile, in return, may have lowered the vulnerability to the risks of financial integration for emerging economies (Didier et al., 2012). In contrast, developed countries are to a great extent relied on external debt in the pre-financial crisis period. As Lane (2012) emphasized, a high debt-equity ratio in external liabilities compared to external assets and profile of most developed economies evidently held risks, and hence financial integration inflated the financial crisis for advanced economies. (Stiglitz, 2010) says global financial market integration was expected to enhance significant financial stability when susceptibility to financial crises were dispersed throughout the world. The occurrence of financial crisis has created uncertainty on this conception. Financial crisis emerged in one part of the global economic system induced a global economic disaster. Therefore, full financial integration is not general optimal. If we are given a choice from two opposite regimes or economic models being as full financial integration and autarky, we may choose an autarky as a higher rank. Yucel (2009) found that trade openness has a positive effect on economic growth, whereas financial development has a negative effect on economic growth. Moreover, his granger causality test results disclosed the existence of bi-causal relationship between financial development, trade openness and economic growth suggesting that economic policies intended at financial development and trade openness have statistically significant impact on economic growth. Stavarek, Rpkova, and Gajdosova (2011) indicated that creating opportunities for risk sharing and diversification, efficient allocation of financial capital, and facilitating a potential for higher economic growth are the three essential benefits of financial integration.

To sum up the above discussion, according to literatures, the discrepancy in research results concerning the role of financial integration in enhancing sustainable economic growth, can be conveyed in four basic views. These are supply leading hypothesis, demand following hypothesis, bidirectional causality (feedback) hypothesis, and independent (neutral) hypothesis. Many researchers like Krimo (2017); Murinde, Frens, and Eng (2010); Odhiambo (2007); Banerjee, Saibal and Gosh (1998); Carby, Craigwell, Wright, and Wood (2012), and others have done their research analysis on this topic. The supply leading hypothesis states a unidirectional causation that flows from financial integration to economic growth entailing that financial markets and financial institutions increase the supply of financial services. 
According to this hypothesis, the stages of financial development suggests a future economic growth. A better developed financial system supplies a good financial service to decrease operation costs and enhance the efficiency of intermediation through mobilizing savings, identifying good projects, facilitating trade, and diversifying risks. These results in a more efficient allocation of financial resources, faster accumulation of human and physical capital, and quicker technological innovation. Hence, induces rapid and sustainable economic growth.

There are also researches indicating results related to demand following hypothesis. Studies consistent with the demand following hypothesis states that there is a unidirectional causation that flows from economic growth to financial development. This connotes increasing demand for financial services and might contribute to the faster and larger expansion of the financial system as the real sector of the economy grows. The development of the real sector economy stimulates increased demand for financial services, which in turn, produces the introduction of new financial institutions and financial markets to meet the increased demand for financial services. The bidirectional causality hypothesis is a combination of the supply leading and demand following hypotheses. The bidirectional causality hypothesis argues that a strong financial system can encourage economic growth and vice versa. ${ }^{4}$ i.e. financial deepening and economic growth have a mutual or bidirectional causal relationship. Financial deepening gradually enhances economic growth, and this induces further financial deepening. The independent hypothesis states that financial deepening and economic growth have no causal relationship.

\section{Methodology}

On the measurement of financial integration, (Baele et al., 2004) indicated that financial integration is often measured through three broad categories of measurements which are price-based measure, news-based measure, and quantity-based measure. Price-based measures discrepancies in prices. The news -based measures the effect of information. If financial sector is not well integration, local news continues to influence local prices. The quantity-based measures the demand and supply of investment opportunities. On the other hand, to measure financial integration, literatures commonly use two direct measures. A restrictive measure offers a qualitative indicator of flow capital controls across border, and an openness measure using actual gross or net capital flows across border. This paper adopts models developed by Edison et al. (2002); Bonfiglioli (2008); Osada and Saito (2010); Karadam and Öcal (2014); Lane and Milesi- Ferreti (2003); and Dogbey (2016) to investigate possible effects of financial integration on Ethiopian economic growth. Similar methods were also applied by Quin (1997); Rodrick (1998); Klein and Olivier (2000); and others. They state the importance of certain economic conditions, such as initial income, stock market and financial market development and inflation.

\footnotetext{
${ }^{4}$ Supply leading hypothesis suggests a positive influence of financial integration on economic growth. Demand following hypothesis states that finance responses to changes that happen in the real sector. Bidirectional causality hypothesis postulates that there is a mutual effect between finance and economic growth. Independent hypothesis on the other hand states that financial deepening and economic growth have no causal relationship.
} 
The model takes the following format:

$$
\mathrm{Y}=\alpha+\beta \mathrm{FI}+\gamma \mathrm{X}+\varepsilon \mathrm{i}
$$

Where, the dependent variable, Y is real GDP per capita growth, FI is one of the measures of financial integration, and $\mathrm{X}$ represents a matrix or vector of control variables. The measures of financial integration variables are chosen from one of the two direct measure of financial integration which is also used by other researchers. Therefore, it is decided to take one of the financial openness indicators in place of FI. That is the stock of capital or flow of capital. That could be broken down as the stock of Foreign Direct Investment (FDI) and equity liabilities, debt liabilities, FDI and equity assets, and debt assets, all of them taken as a share of nominal GDP.

Many previous researchers used various variables of macroeconomic indicators as a vector of control variables. The vector of control variables might include years of schooling as a proxy for human capital, population growth, inflation rate, terms of trade taken as the price of exports divided by the price of imports, trade openness calculated as the sum of exports and imports divided by GDP, a variable that measures the extent of domestic financial depth which is the stock of domestic private credit as a ratio of nominal GDP, and a measure of institutional quality (Osada and Saito, 2010). Financial depth proxied by the ratio of total credit to the private sector over GDP and its growth rate, government expenditure as a share of GDP, openness to trade proxied by import plus export as a share of GDP, Intellectual property right, Institutional quality proxied by the Government anti-diversion policy index, economic development, deposit insurance, and inflation were used as a vector of control variables by (Bonfiglioli,2008). Edison et al. (2002) used initial income as logarithm of real per capita GDP in the initial year of the period under consideration, initial schooling as logarithm of the average years of secondary schooling, private credit as logarithm of credit to the private sector by deposit money banks and other financial institutions as a share of GDP, stock activity as logarithms of the total value of domestic stock transactions on domestic exchanges as a share of GDP, Inflation as growth rate of the consumer price index, and government balance as government fiscal balance divided by GDP as a vector of control variables. Eyraud, Singh, and Sutton (2017) used three alternative integration indices which are external openness as stock of external assets plus liabilities as a ration to GDP or external liability to GDP ratio, a measure of financial depth as a ratio of private sector credit provided by banks to GDP, and regional openness as a ratio of regional assets and liabilities to total foreign assets and liabilities of a given country.

Therefore, this paper decides to use an openness measure of financial integration to examine the impact of global financial integration on Ethiopian economic growth. Doing so, based on the above listed research papers that made their studies on the relationship between financial integration and economic growth and other supportive evidences, this paper uses GDP per capita as a dependent variable and financial integration as an independent variable. Financial openness indicators are used as a proxy for financial integration and variables like school enrolment rate, population growth, inflation rate, trade openness, and financial depth which is proxied by credit to private sector are used as control variables. 


\section{Data analysis and Results}

The time series annual data from 1980 to 2017 is collected from National Bank of Ethiopia and World Bank. The model used is a time series multilinear regression model. The Ordinary Least square (OLS) regression technique is applied for modelling and analyzing variables using statistical and econometric package (EViews). OLS is a statistical method for estimating linear regression model producing one straight line that minimizes the total squared error. It fits the function with the data by minimizing the sum of squared errors from the data. Assuming linearity in parameters, random sampling of observations, zero conditional mean, no multicollinearity or perfect collinearity, there is homoscedasticity, no autocorrelation, normally distributed error terms, and number of observations must be greater than number of parameters to be estimated. According to Gauss-Markov theorem ${ }^{5}$, OLS estimator is Best Linear Unbiased Estimator (BLUE), if the above listed assumptions are met.

The multilinear regression model has the following form:

$$
\begin{gathered}
\text { GDPPC: F (DCP, FFL, SSE, PPG, INF, TOP, TOT }) \\
\text { GDPPC }=\alpha+\beta_{1} \mathrm{DCP}+\beta_{2} \mathrm{FFL}+\beta_{3} \mathrm{INF}+\beta_{4} \mathrm{PPG}+\beta_{5} \mathrm{SSE}+\beta_{6} \mathrm{TOP}+\beta_{7} \mathrm{TOT}+\varepsilon
\end{gathered}
$$

Where,

GDPPC is GDP per capita,

DCP is domestic credit to private sector as a percentage of GDP,

FFL is net financial flow,

SSE is secondary school enrolment rate,

PPG is population growth rate,

TOP is trade openness, INF is inflation rate, and

TOT is term of trade

Null hypothesis, $\mathrm{H} 0: \beta 1=\beta 2=\beta 3=\ldots=0$

Alternate hypothesis, $\mathrm{H} 1: \beta 1 \neq \beta 2 \neq \beta 3 \neq \ldots \neq 0$, at least one $\beta$ differs from zero.

For individual variables we make

Null hypothesis, $\mathrm{H} 0: \beta 1=0$

Alternate hypothesis, $\mathrm{H} 1: \beta 1 \neq 0$

The model has 38 observations, one dependent and seven independent variables. The GDP

\footnotetext{
5 The Gauss-Markov theorem states that if the linear regression model fulfils the assumptions, then the ordinary least squares (OLS) estimator of the coefficients of a linear regression model is the best linear unbiased estimators (BLUE). And the OLS regression creates unbiased linear estimates that have the smallest variance of all the possible linear estimators.
} 
per capita is used as a dependent variable whereas domestic credit to private sector as a percentage of GDP, net financial flow, secondary school enrolment rate, population growth rate, trade openness, inflation rate and term of trade are used as an independent variable. The regression analysis result shows that in the regression model (1), population growth rate, inflation rate, and terms of trade variables are statistically insignificant because their probability or $\mathrm{p}$-value is greater than the usual significance level. The $\mathrm{p}$-value is not low enough to reject the null hypothesis with significance level of $0.01,0.05$, or 0.1 . This indicates that the data for these three variables does not provide enough evidence to reject the null hypothesis. In other words, there is insufficient evidence in the data to conclude that a non-zero correlation exists and there is not enough evidence to conclude that these three variables influence the dependent variable. Apart from the $\mathrm{p}$-value, considering the $\mathrm{t}$-value test, the absolute value of calculated t-test is less than the critical value for all the three variables. Therefore, this t-value test result also supports the p-value indicating that, we fail to reject the null hypothesis at the significance level indicated earlier.

However, Other variables that are included in the model such as domestic credit to private sector as a share of GDP, net financial flow, secondary school enrolment rate, and trade openness are statistically significant showing their p-value is less than usual significant levels $(1 \%, 5 \%$ or $10 \%)$ or $(0.0,0.05,0.1)$. The t-test result also leads as to similar conclusion where its absolute t-value is greater than the critical value. Therefore, we reject the null hypothesis. The overall model of fit indicates that the value of the coefficient of determination (R2), and the value of adjusted R2 are 0.93 and 0.91 respectively. These results indicate that $91 \%$ of the model explains the observed variation in the dependent variable relative to the mean. And the P-value of F- statistic is statistically significant. Therefore, these results indicate that the overall model is statistically significant, meaning it is a model of good fit.

Let us see the second model by removing statistically insignificant variables from the first regression model (1). Hence, the regression function will have the following form:

GDPPC: F (DCP, FFL, SSE, TOP)

Now, the seven independent variables in the first model (1) reduced to four independent variables in the second regression model (2). And the regression model becomes:

$$
\mathrm{GDPPC}=\alpha+\beta_{1} \mathrm{DCP}+\beta_{2} \mathrm{FFL}+\beta_{3} \mathrm{SSE}+\beta_{4} \mathrm{TOP}+\varepsilon
$$

Where,

GDPPC is GDP per capita,

DCP is domestic credit to private sector as a percentage of GDP,

FFL is net financial flow,

SSE is secondary school enrolment rate,

TOP is trade openness.

In this regression model (2), the regression result indicates that considering both t-tests and 
p-values for all individual variables, all the independent variables are statistically significant. Therefore, we reject the null hypothesis. Furthermore, the result of R2, adjusted R2, and P-value of F-statistic indicates the regression model explains more than $91 \%$ of the observed variation in the dependent variable and the model is statistically significant. The coefficient of all the variables are positive while that of the trade openness is negative. A positive coefficient indicates that there is a positive relationship between the dependent variable and independent variables and suggests that as the value of the independent variable increases, the mean of the dependent variable tends to increase. Whereas, a negative coefficient shows that there is a negative correlation between the two variables and proposes as the independent variable increases, the dependent variable tends to decrease. On the other hand, the value of the coefficients indicates how much the mean of the dependent variable changes when a one-unit change occurs on independent variable, keeping other variables constant.

Literatures on the theory of financial integration suggests that, for a country to get benefit from financial integration, the development of financial system, development of financial infrastructure, and level of economic development matters. In Ethiopian case, the regression analysis result shows that the coefficient of net financial flow which is taken as a proxy for financial integration is positive and statistically significant. This means that though the economic development of the country, level of financial development, and level of financial integration is not that strong; net financial flow is positively contributing to the economic growth of the country. In addition to that, the coefficient of the domestic credit to private sector as a share of GDP which is taken as a proxy to the domestic financial depth is positive and statistically significant. i.e. it shows the positive contribution the domestic financial sector to the financial system and to the economic growth of the country. However, trade openness indicator has a negative sign and statistically significant, which suggests at the current economic growth level of the country, openness is affecting the economy of the country negatively.

\section{Conclusion}

The objective of this paper and the reason why this topic is chosen was as it is clearly tried to be presented in introduction and subsequent part of this paper, the link between the financial integration and economic growth is yet somehow controversial. Therefore, this paper aims at investigating the role of financial integration on Ethiopian economic growth to see how Ethiopia's economy is being affected by international financial integration. Even though most of the research results indicated the benefit of financial integration, but still there is doubt on the impact of financial integration on economic growth specially in relation to vulnerability of developing countries to the global financial crisis. This incertitude or uncertainty is loudly heard particularly after the major financial crisis in different part of the world had occurred. A country can be financially integrated regionally or globally. However, most financial integrations tend to have increased financial links with major world financial centers. Because, the global network externalities give the major world financial centers an advantage in the provision of financial services. However, geographical closeness is a crucial determinant of international trade and financial capital flows across borders. Therefore, economic growth is given a very good promotion by prioritizing a regional financial market 
integration.

Opening financial markets and financial institutions to foreigners and letting domestic market players to invest overseas are actions of financial integration processes. This is done through removing obstacles to cross-border flow of capital and financial services. One of the steps towards an integrated financial market is, the removal of barriers which result in mistreatment of foreign capital and foreign financial institutions. That is why, in the last few decades, several industrialized and developing countries have liberalized their financial system. To liberalize their financial system, they eased or lifted bank interest rate ceilings, reduced entry barriers, lowered reserve requirements, reduced involvement of government in credit allocation decisions, privatized banks and insurance companies, developed stock market, and promoted entry of foreign financial intermediaries. As a result, they lost access to international capital market during the financial crisis due to quick reversal or stops of capital flow. Their dependence on short-term debt financing also entails that their public and private sectors are required to pay back existing debts. The problem is intensified by the fact that their debts are usually denominated in a foreign currency.

The sudden stops of capital inflow or quick reversal of capital inflow during financial crisis; may force a country into a situation where it is not able to service its debt or reduce the productivity of existing capital stock. when a financial crisis occurs and access to international capital markets is lost, the policy options available for developing countries are seriously limited. Expansionary economic policies, which could potentially countervail some of the crushing effects of capital flow reversals, are possible only under capital control. We need to remember the issue of trilemma. Thus, due to the international financial integration, the financial crisis happened in one part of the world can easily spread to other part of the world. Literatures indicate that, the research results on the assessment of the role of financial integration on economic growth varies. Because, for a country to reap up benefit from financial integration, composition of financial flow and level of financial integration matters. A country with a more developed financial sector and a good integration level, benefits more from financial integration.

The international financial integration is part of the integration of the national economies into the world economic system. This financial integration is one of the most significant developments of the last century. In today's global economic system, countries trade both final products and intermediate goods. This forms a composite network of economic interactions that include the whole world. The integration of national economies into global economic system creates the potential factors that enhance economic growth. These are competition, economies of scale, and innovation. When a country opens to the world, the demand and supply of goods and services in the economy changes. As a result, local market responds to the new phenomenon and a change in price occurs in the local market. This change in local price has an impact on the households and firms. This indicates that the financial integration has an impact on individual level as well. Financial integration requires development of financial system and non-financial institutions to support and smooth transactions. 


\section{Mll Macrothink}

Business and Economic Research ISSN 2162-4860 2020, Vol. 10, No. 1

The data analysis result indicates financial flow which was taken as a proxy for financial integration has a positive impact on economic growth and statistically significant. In addition to that the domestic credit to private sector which was a proxy for the financial depth also has a positive impact and statistically significant. However, the trade openness has a negative impact on the economic growth. Therefore, the result of this analysis indicates that the financial integration has a positive impact on the Ethiopian economic growth. This result is supported by other literatures that suggest, financial integration has a positive effect on economic growth by reducing asymmetric information, reducing transaction costs, increasing competition and efficiency. On the other hand, Ethiopia's financial sector openness to the world financial market may expose the economy of a country for an increased vulnerability to external economic shocks and financial crises. Exposure to financial crisis and consumption volatility are the worst side effects of financial integration. Therefore, to benefit more from Ethiopia's financial sector integration to the world financial market, the country needs to develop its financial sector to be competent enough ahead of fully opening to the world. Because, the current level of economic development and financial sector infrastructure may reduce the benefit the country could get from financial integration in fostering economic growth.

\section{References}

Baele, L., Ferrando, A., Hördahl, P., Krylova, E., \& Monnnet, C. (2004). Measuring Financial Integration in the Euro Area. European Central Bank, 14, 1-98. [Online] Available: https://www.ecb.europa.eu/pub/pdf/scpops/ecbocp14.pdf

Baltzer, M., Cappiello, L., De Santis, A. R., \& Manganelli, S. (2008). Measuring Financial Integration in New EU Member States. European Central Bank, 81, 1-38. [Online] Available: https://www.ecb.europa.eu/pub/pdf/scpops/ecbocp81.pdf

Banerjee, S., \& Ghosh, S. (1998). Demand Following and Supply Leading Relationships: An Empirical Analysis for India. MPRA, 1, 67-82. [Online] Available:

https://mpra.ub.uni-muenchen.de/22443/1/MPRA_paper_22443.pdf

Bekaert, G., \& Harvey, C. (2000). Foreign Speculators and Emerging Equity Markets. Journal of Finance, 55, 565-613. https://doi.org/10.1111/0022-1082.00220

Bonfiglioli, A. (2008). Financial Integration, Productivity and Capital Accumulation. Journal of International Economics, 76, 1-29. https://doi.org/10.1016/j.jinteco.2008.08.001

Brouwer, G. (2005). Monetary and Financial Integration in Asia: Empirical Evidence and Issues. Asian Development Bank, 269-293. [Online] Available:

https://researchers.anu.edu.au/publications/34829

Carby, Y., Craigwell, R., \& Wright, A. (2012). Finance and Growth Causality: A Test of the Patrick's Stage-of-Development Hypothesis. International Journal of Business and Social Science, 3(21), 1-11. [Online] Available:

http://www.ijbssnet.com/journals/Vol_3_No_21_November_2012/14.pdf

Claessens, S., Laeven, L., lgan, D., \& Dell'Ariccia, G. (2010). Lessons and Policy 
Implications from the Global Financial Crisis. IMF Working Papers, 44(10), 1-37. https://doi.org/10.5089/9781451963021.001

Didier, T., Hevia, C., \& Schmukler, S. (2012). How Resilient and Counter-cyclical were Emerging Economies During the Global Financial Crisis? Journal of International Money and Finance, 31(8), 2052-2077. https://doi.org/10.1016/j.jimonfin.2012.05.007

Dogbey, J., \& Dogbey, J. (2016). The Impact of Financial Integration on Growth-Volatility Relationship - A Reappraisal. Global Journal of Management and Business Research: C Finance, 16(2249-4588), 69-76. [Online] Available:

https://globaljournals.org/GJMBR_Volume16/E-Journal_GJMBR_(C)_Vol_16_Issue_1.pdf

Edison, H., Levine, R., Ricci, L., \& Slok, T. (2002). International Financial Integration and Economic Growth. Journal of International Money and Finance, 21(6), 749-776.

https://doi.org/10.1016/S0261-5606(02)00021-9

Edison, H., Klein, M., Ricci, L., \& Slok, T. (2002). Capital Account Liberalization and Economic Performance: Survey and Synthesis. The National Bureau of Economic Research, 51(2), 1-39. https://doi.org/10.3386/w9100

Eichengreen, B. (2010). The Breakup of the Euro Area. The National Bureau of Economic Research, 11-51.https://doi.org/10.7208/chicago/9780226012858.003.0002

Eyraud, L., Singh, D., \& Sutton, B. (2017). Benefits of Global and Regional Financial Integration in Latin America. IMF Working Papers, 1(17), 1-32.

https://doi.org/10.5089/9781475568684.001

Frankel, J., \& Saravelos, G. (2012). Are Leading Indicators Asses Country Vulnerability? Evidence from the 2008-09 Global Financial Crisis. Journal of International Economics, 87(2), 216-231. https://doi.org/10.1016/j.jinteco.2011.12.009

Frey, L., \& Volz, U. (2013). Regional Financial Integration in Sub-Saharan Africa-An Empirical Examination of its Effects on Financial Market Development. South African Journal of Economics, 81(1), 79-117. https://doi.org/10.1111/j.1813-6982.2012.01334.x

Giannone, D., Lenza, M., Pill, H., \& Reichlin, L. (2011). Non-Standard Monetary Policy Measures and Monetary Developments. European Central Bank, 1290, 1-33.

https://doi.org/10.1017/CBO9781139044233.008

The Global Financial and Monetary System in 2030. (2018). World Economic Forum, 1-22. [Online] Available:

https://www.weforum.org/reports/the-global-financial-and-monetary-system-in-2030

The Road to ASEAN Financial Integration: A Combined Study on Assessing the Financial Landscape and Formulating Milestones for Monetary and Financial Integration in ASEAN. (2013). Asian Development Bank, 1-34. [Online] Available:

https://www.adb.org/sites/default/files/publication/30202/road-asean-financial-integration.pdf

Henry, P. (2000). Stock Market Liberalization, Economic Reform, and Emerging Market 


\section{Macrothink}

Business and Economic Research ISSN 2162-4860 2020, Vol. 10, No. 1

Equity Prices. The Journal of Finance, 55(2), 529-564.

https://doi.org/10.1111/0022-1082.00219

Jappelli, T., \& Pagano, M. (2008). Financial Market Integration under Economic and Monetary Union (EMU). European Economic Commission, 1-32. [Online]

Available:https://ec.europa.eu/economy_finance/publications/pages/publication12323_en.pdf

IMF Annual Report. (2016). IMF.1-131. [Online] Available:

https://www.imf.org/external/pubs/ft/ar/2016/eng/pdf/ar16_eng.pdf

Yolcu, D., \& Ocal, N. (2014). Financial Integration and Growth: A Nonlinear Data Analysis. Economic Research Center Working Papers. [Online] Available:

https://ideas.repec.org/p/met/wpaper/1415.html

Karimo, T., \& Ogbonna, O. (2017). Financial Deepening and Economic Growth Nexus in Nigeria: Supply-Leading or Demand-Following. Economies, Open Access Journal, 5(1), 1-18. https://doi.org/10.3390/economies5010004

Klein, M., \& Olivei, G. (2005). Capital Account Liberalization, Financial Depth and Economic Growth. NBER Working Papers. 1-32. [Online] Available:

https://core.ac.uk/download/pdf/6501788.pdf

Kose, A., Prasad, E., \& Terronnes, M. (2003). Financial Integration and Macroeconomic Volatility. International Monetary Fund, 50(3), 119-138.

http://dx.doi.org/10.2139/ssrn.393420

Kose, A., Prasad, E., \& Terronnes, M. (2009). Does Financial Globalization Promote Risk Sharing? Journal of Development Economics, 89(2), 258-270.

https://doi.org/10.1016/j.jdeveco.2008.09.001

Lane, P. (2012). Financial Globalization and the Crisis. BIS Working Papers, 397, 1-42.

[Online] Available: https://www.bis.org/publ/work397.htm

Lane, P., \& Shambaugh, J. (2010). Financial Exchange Rates and International Currency Exposures. American Economic Review, 100(1), 518-540.

https://doi.org/10.1257/aer.100.1.518

Lane, P., \& Milesi-Ferretti, G. (2007). Europe and Global Imbalances. IMF Working Papers, 144(7), 1-61. https://doi.org/10.5089/9781451867084.001

Lane, P., \& Milesi-Ferretti, G. (2011). External Adjustment and the Global Crisis. NBER Working paper. 1-49. https://doi.org/10.3386/w17352

Lane, P., \& Milesi-Ferretti, G. (2003). International Financial Integration. IMF Working Paper, 86(3), 1-37. https://doi.org/10.5089/9781451850901.001

Levine, R. (2001). International Financial Liberalization and Economic Growth. Review of International Economics, 9(4), 688-702. https://doi.org/10.1111/1467-9396.00307

Murinde, V., \& Eng, F. (2010). Financial Development and Economic Growth in Singapore: 
Demand-Following or Supply-Leading? Applied Financial Economics, 4(6), 391-404. https://doi.org/10.1080/758518671

Odhiambo, N. (2007). Supply-Leading versus Demand-Following Hypothesis: Empirical Evidence from three SSA Countries. African Development Review, 19(2), 257-280. https://doi.org/10.1111/j.1467-8268.2007.00161.x

Osada, M., \& Saito, M. (2010). Financial Integration and Economic Growth: An Empirical Analysis Using International Panel Data from 1974-2007. Bank of Japan Working Paper. 1-11. [Online] Available:

https://pdfs.semanticscholar.org/a3b1/de4452454e6cccc7f2b0c6080e1e12e563e0.pdf

Prasad, E. (2011). Role Reversal in Global Finance. NBER Working Paper. 339-390. https://doi.org/10.3386/w17497

Prasad, E., Rogoff, K., Wei, S., \& Kose, A. (2003). Effects of Financial Globalization on Developing Countries: Some Empirical Evidence. International Monetary Fund. 1-86. https://doi.org/10.5089/9781498329835.007

Quinn, D. (1997). The Correlates of Change in International Financial Regulation. American Political Science Review, 91, 531-551. https://doi.org/10.2307/2952073

Rodrik, D. (1998). Trade Policy and Economic Performance in Sub-Saharan Africa. NBER Working paper. 1-74. https://doi.org/10.3386/w6562

Rose, A., \& Spiegel, M. (2010). Cross-Country Causes and Consequences of the Crisis: An Update. NBER Working Paper. 1-34. https://doi.org/10.3386/w16243

Syavarek, D., Repkova, I., \& Gajdosova, K. (2011). The Theory of Financial Integration and Achievements in the European Union. MPRA.1-26. [Online] Available: https://mpra.ub.uni-muenchen.de/34393/1/MPRA_paper_34393.pdf

Stiglitz, J. (2010). Risk and Global Economic Architecture: Why Full Financial Integration May be Undesirable. American Economic Review, 100(2), 388-92.

https://doi.org/10.1257/aer.100.2.388

Yucel, F. (2009). Causal Relationship between Financial Development, Trade Openness and Economic growth: The Case of Turkey. Journal of Social Sciences, 5(1), 33-42.

https://doi.org/10.3844/jssp.2009.33.42

Economic Report on Africa. (2008). Africa and the Monterrey Consensus: Tracking performance and Progress. United Nations Economic Commission for Africa. 1-202. [Online] Available: https://www.uneca.org/sites/default/files/PublicationFiles/era2008full.pdf 


\section{Copyright Disclaimer}

Copyright for this article is retained by the author(s), with first publication rights granted to the journal.

This is an open-access article distributed under the terms and conditions of the Creative Commons Attribution license (http://creativecommons.org/licenses/by/3.0/). 